\title{
O VAI E VEM DOS CONCEITOS: DE CATEGORIA ANALÍTICA A CATEGORIA NATIVA OU VICE-VERSA. O CASO DO SINCRETISMO.
}

\author{
Melvina Araújo ${ }^{1}$
}

Resumo: Pretendo, neste texto, analisar o trânsito da categoria sincretismo, utilizada ora como categoria analítica ora como categoria nativa. Para tanto, tomo como objeto a discussão teológica sobre a elaboração de uma teologia do sincretismo, bem como debates em torno da teologia índia e também discussões acerca da noção de sincretismo travadas no interior das ciências sociais.

Palavras-chave: Religião; Sincretismo; Cultura; Teoria antropológica.

Abstract: I intend, in this text, analyze the traffic in the syncretism's category, sometimes used as an analytical category either as native category. For this I take as object the theological discussion on developing a theology of syncretism as well as debates about the Indigenous theology also discussions about the notion of syncretism waged within the social sciences.

Keywords: Religion; Syncretism; Culture; Anthropology theory.

${ }^{1}$ Graduada em Ciências Sociais pela Universidade Estadual de Londrina (1992), mestre e doutora em Antropologia Social pela Universidade de São Paulo. É docente da Universidade Federal de São Paulo e desenvolve o projeto de pesquisa Alteridade e mediação: processos de construção do "outro" em universos católicos e protestantes no Brasil e na África. Seus trabalhos enfocam principalmente temas como relaçoes interculturais, missões, antropologia dos mediadores, concepçōes sobre o corpo, saúde e doença. 
Chamou-me a atenção ${ }^{2}$, ao participar do IV Congresso Internacional de Ciências da Religião, em Goiânia, a afirmação contundente de que o sincretismo existe. Mais do que isso, além de pairar o consenso em torno da existência do sincretismo, havia uma pergunta, colocada tanto por parte do público quanto por parte de alguns dos conferencistas, concernente às possibilidades de tratamento do sincretismo no interior das religiões. Este tipo de preocupação vindo de pesquisadores que se debruçam sobre temas relativos às religiōes, com formaçôes as mais variadas, como em ciências da religião, teologia, filosofia, psicologia, sociologia e antropologia, coloca em pauta a questão do deslizamento de categorias acadêmicas para categorias nativas, ou vice versa, assim como os tratamentos teóricos dados ao tema das relações interculturais. Assim sendo, interessa, neste artigo, analisar o debate que perpassa os espaços religiosos no que concerne ao modo de lidar com a alteridade. Ou seja, interessa compreender como se desenrola o debate sobre as diferentes formas de ver o mundo e viver experiências de cunho religioso, observando o trânsito entre campos de conhecimento, bem como as alterações de sentido de certas categorias decorrentes desse trânsito.

Comecemos, pois, com a discussão acerca da formulação da teologia do sincretismo, para posteriormente puxarmos alguns fios que nos permitirão discutir as questões acima propostas.

\section{SINCRETISMO: CATEGORIA EM TRÂNSITO}

A proposta de elaboração da teologia do sincretismo advém de uma discussão sobre alguns dos preceitos da teologia da inculturação que teria, segundo Afonso Ligorio Soares $^{3}(2009)$, como pressuposto a existência de uma maneira correta, ou ortodoxa, para o cristianismo se relacionar com outras religiões. Esta maneira deveria ser, ainda segundo o autor, capaz de

${ }^{2}$ A surpresa refere-se, sobretudo, à contundência da afirmação, pois, como veremos adiante, o uso do termo sincretismo como dado não é novidade.

3 Afonso Ligório Soares é teólogo e professor do Programa de Pós-Graduação em Ciências da Religião da PUC-SP. 
assegurar a "verdade do rito". Ao contrário da teologia da inculturação, prossegue o autor, a teologia do sincretismo "[...] consiste em reconhecer o sincretismo de fato e estudar sua lógica interna"“ (2009, p. 44). Propõe Soares (2010, p. 47):

[...] é preciso identificar o modo mesmo de uma fé se concretizar ou ser traduzida, uma vez que não existe fé em estado puro; ela só se mostra na práxis. Aqui entendo como praticamente sinônimos o sincrético, o histórico, o concretizado e o traduzido. O que procuro evitar quanto possível é simplesmente chamar esse processo de inculturação, pois existe aí uma diferença de trajeto, ou seja, o ponto de vista de onde se observa a criatividade religiosa do povo em ação. Quando digo fé sincrética tenciono salientar a autocomunicação divina já atuante nas várias tradições culturais antes, contra ou mesmo apesar do contato com as comunidades cristãs.

A crítica dirigida pelo autor à teologia da inculturação parece pautar-se, sobretudo, em duas questóes que, por vezes, cruzam-se. A primeira referese ao modo como elementos de outras tradições religiosas poderiam ser incorporados na liturgia e/ou doutrina católica e, a segunda, à afirmação da existência de uma única doutrina válida. Nesse sentido, o autor chama a atenção para as discussões, tecidas por alguns teólogos da inculturação, em torno do perigo de desvio da doutrina. De acordo com a leitura de Soares (2010), para esses autores, na inculturação, seria necessário observar, nas culturas nativas, o que há de bom e divino e fortalecer estes pontos e, ao mesmo tempo, trabalhar de maneira a suprimir o que for considerado ruim ou não condizente com a ética cristã. Além disso, nos princípios da teologia da inculturação, não haveria lugar para a criação de um espaço que pudesse abrigar várias doutrinas religiosas, o que pressuporia a necessidade de todas, de uma maneira ou de outra, tornarem-se católicas.

A teóloga Irene Oliveira (2008) concorda com as críticas feitas por Soares à teologia da inculturação. Segundo ela:

4 Itálico no original. 
A inculturação diz respeito ao encontro da mensagem evangélica com as diferentes culturas. Consiste numa ação que visa adentrar-se numa cultura estranha, apropriar-se da mesma com a finalidade de transmitir a mensagem religiosa. Para alguns pesquisadores(as) esta apropriação acompanha a suspeita de um intervencionismo cultural que visa a conversão do outro, não com meios violentos mas com suavidade. A inculturação também é vista como um processo de "apropriação" espontânea e voluntária, por parte de um determinado grupo, de uma religião, ou de elementos desta e que serão expressos e comunicados a partir de sua determinada cultura, linguagem e símbolos. (Oliveira, 2008, p. 3).

Desse modo, a autora parece se posicionar contrariamente à teologia da inculturação, em virtude dessa ter como suposto que o outro será evangelizado. Isso, segundo a autora, seria, além de uma apropriação de elementos culturais do outro para introduzir, em seu meio, uma religião, uma forma de desconsideração dos valores e sentidos dos outros, impedindo que suas crenças e filosofias sejam consideradas tão válidas quanto a cristã.

No entanto, se, por um lado, Irene Oliveira (2008), faz uma crítica bastante contundente à teologia da inculturação, defendendo o reconhecimento de outras manifestações religiosas, por outro, a autora afirma não ver diferença entre inculturação e sincretismo. Para ela, inculturação parece um “outro nome para o 'sincretismo' religioso" (2008, p. 3). O que ocorre, continua, é que o termo sincretismo tem uma repercussão negativa no interior do cristianismo e, por este motivo, teria sido substituído pelo termo inculturação.

A negatividade do termo sincretismo, de acordo com Irene Oliveira (2008), adviria de sua associação com as religiōes afro-brasileiras e com práticas culturais das classes dominadas. Nesse sentido, faz-se necessário lembrar o movimento antissincretismo, surgido na década de 1980, que congregava adeptos das religiôes afro-brasileiras. $\mathrm{O}$ mote desse movimento centrava-se na busca das origens africanas das religiōes afro-brasileiras e na supressão dos elementos advindos das tradições cristãa ${ }^{5}$.

5 Ver, sobre este tema, Ferreti (2007), Birman (2001), Sanchis (2001), entre outros. 
Em relação à disputa semântica entre inculturação e sincretismo, o jesuíta Mario de França Miranda (2001) argumenta que o termo sincretismo tem sua origem em Plutarco ${ }^{6}$ e significava a união das cidades cretenses contra uma terceira cidade. Seu significado foi-se modificando com o passar do tempo e - o que mais interessa no argumento aqui exposto - reapareceu como um instrumento utilizado nas ciências da religião no século XIX. Neste contexto, o termo foi utilizado em estudos sobre a história do cristianismo para descrever a absorção, pelo cristianismo, de elementos culturais e religiosos dos contextos nos quais estava inserido.

Já o termo inculturação, teve seu sentido definido mais recentemente na reflexão teológica, afirma Miranda (2001). O argumento que norteou essa reflexão foi o de que, para que a fé possa ser "captada e vivida num contexto diferente, deve incorporar os novos traços culturais para poder se constituir, expressar e ser uma realidade viva" (2001, p. 110). Nesse sentido, quando ocorre o encontro entre duas culturas ou entre uma religião e uma cultura, o termo sincretismo pode aproximar-se do sentido do termo inculturação, mas esses termos não têm o mesmo significado, pois continua o autor, o que interessa na inculturação não são as transformações que resultam deste encontro, mas "[...] $a$ incidência da dimensão religiosa da cultura no cristianismo” (2001, p. 110). Desse modo, prossegue Miranda, o sincretismo seria uma fase do processo de inculturação.

Nas ciências da religião, segundo Miranda (2001), sincretismo não tem um sentido positivo ou negativo, embora haja discordância em relação à sua acepção. Já na teologia, haveria uma preocupação em definir o que

${ }^{6}$ A etimologia do vocábulo sincretismo é, segundo Houaiss (2001, p. 2577), a seguinte: "ETIM gr. sugkrētismós, ou 'união de cretenses contra um adversário comum', donde 'coligação de dois adversários contra um terceiro', de sún 'conjuntamente, ao mesmo tempo' e v. krētizō 'agir como um cretense, p. ext., agir como um velhaco, ser impostor', pelo fr. syncrétisme (1611) 'uniāo de dois antigos inimigos contra uma terceira pessoa', (1687) 'tentativa de promover a fusão de diversos cultos, diversas doutrinas religiosas', (1765) 'tentativa de reunião, de síntese de várias doutrinas filosóficas', (1890) PSIC 'apreensão global, mais ou menos confusa, de um todo', (1909) 'apreensão global, indiferenciada, que precede a percepção e o pensamento em relação a objetos nitidamente distintos uns dos outros', (1933) na acp. de LING; f. hist. 1858 syncretismo”. 
seria um sincretismo verdadeiro e um sincretismo falso. Segundo o autor, é o que faz, por exemplo, Leonardo Boff (1981, apud Miranda, 2001) que estabelece critérios para distinguir o verdadeiro sincretismo. Este teria como pressuposto a tentativa de resguardar a identidade cristã no processo de incorporação de elementos alheios.

Ora, se tomarmos a noção de sincretismo tal qual definida anteriormente, ela seria dotada dos mesmos elementos que Irene Oliveira (2008) pensa serem problemáticos na noção de inculturação. Ou seja, a aceitação de elementos advindos de outras culturas ou religiôes estaria vinculada ao fato de não colocar em risco a identidade cristã da doutrina e dos ritos. A autora, no entanto, esclarece que, apesar das acepções negativas dadas ao termo sincretismo - por teólogos, alguns autores das ciências sociais e, sobretudo, por adeptos de religióes afro-brasileiras -, há autores que defendem seu uso e caráter positivo, como Pierre Sanchis (2001), por exemplo.

Deste modo, para a autora, seria necessário conceber o sincretismo como um espaço no qual possam conviver elementos de diferentes tradições culturais e religiosas, pois o fato de se insistir na homogeneização religiosa suprimiria a possibilidade de se conhecer outras filosofias e doutrinas religiosas.

Em suma, apesar das diferentes acepções do termo sincretismo nas ciências da religião e/ou na teologia, o que está em jogo no debate que permeia os espaços religiosos relaciona-se à questão de como lidar com a alteridade ou, dito de outro modo, como lidar com diferentes formas de ver o mundo e vivenciar experiências de caráter religioso. Nesse sentido, há outras discussões teológicas que propõem também formas de considerar rituais e concepções indígenas concernentes à relação com o sobrenatural como tão verdadeiras quanto as concepções cristãs. No entanto, enquanto a discussão em torno da teologia do sincretismo circunscreve-se, sobretudo, ao universo das religiōes afro-brasileiras, nos contextos ameríndios o que está em pauta é a teologia índia. 


\section{TEOLOGIA ÍNDIA}

Enquanto realizávamos, João Roberto Bort Júnior e eu, uma etapa do trabalho de campo para o desenvolvimento desta pesquisa, na missão Catrimani ${ }^{7}$, em dezembro de 2010/janeiro de 2011, os missionários e alguns Yanomami acertavam os detalhes para a realização de mais um encontro de xapuri ${ }^{8}$, em fevereiro de 2011. A discussão sobre a organização do encontro de xapuri aconteceu no prédio da escola, na missão, um dia depois do término de um curso de formação para os Agentes Indígenas de Saúde - AIS -, cujo encerramento contou com a presença dos responsáveis pelo gerenciamento das açôes de saúde no Distrito Sanitário Especial Indígena Yanomami - DSEI Yanomami -, Claudete Shuertz e Oneron de Abreu Pithan, do bispo de Roraima, D. Roque Paloschi, de David Kopenawa', de tuxauas ${ }^{10}$ xapuris e professores indígenas.

$\mathrm{Na}$ reuniáo realizada para acertar os detalhes do encontro, os xapuri, AIS, tuxauas e professores indígenas ${ }^{11}$ presentes organizaram uma lista de convidados, atentando para não esquecerem nenhum xapuri da área indígena Yanomami. Pairava uma classificação dos convidados como grande xapuri, xapuripata $^{12}$, os xapuri menores e os aprendizes, mas todos seriam convidados. Terminada a lista dos convidados, iniciou-se a organização desses em grupos que deveriam se reunir em locais nos quais há pista de pouso, para que pudessem ser trazidos ao local mais próximo da maloca na qual o encontro foi realizado, Pookohipiitheri.

Enquanto, de um lado, os indígenas organizavam a lista de convidados, dentre os quais também estavam incluídos os missionários da Consolata que

\footnotetext{
${ }^{7}$ A missão Catrimani situa-se na área indígena Yanomami, em Roraima.

8 Xamãs.

${ }^{9}$ A presença desses foi também motivada pela inauguração do novo posto de saúde, reconstruído pelos missionários, com uma pequena contribuição da Fundação Nacional da Saúde - Funasa.

${ }^{10}$ Chefe.

${ }^{11}$ Algumas pessoas são, ao mesmo tempo, AIS e xapuri, professor e xapuri, tuxaua e xapuri etc.

12 Xamãs mais poderosos, sábios.
} 
trabalham na missão Catrimani e outros cuja presença consideram importante - como a de um jesuíta que já participou de outro encontro de xapuri e submeteu-se ao ritual de iniciação xapurimu ${ }^{13}$-, de outro, os missionários, sob a coordenação da irmã Napëuxi ${ }^{14}$, cuidavam de alguns aspectos relativos ao transporte das pessoas para o local do encontro, à divisão do trabalho de provisão de alimentos para os participantes do encontro, dentre outros. Nesse caso, a grande preocupação centrava-se no levantamento de recursos para custear o aluguel das aeronaves necessárias para transportar pessoas que se encontrariam em vários pontos da área Yanomami e em Boa Vista ${ }^{15}$. Quanto à provisão de alimentos, alguns grupos foram encarregados de levar peixes e caças - macaco, javali, anta, jacaré, por exemplo -, a outros coube o encargo de levar mandioca, beiju, banana, pupunha etc.

Ao mesmo tempo programava-se também a ida de alguns índios e missionários ao encontro de teologia índia, que ocorrerá em 2011.

Diante desse quadro organizativo, quisemos saber como e quando ${ }^{16}$ os encontros de xapuri começaram a ser realizados, de quem foi a iniciativa de realizá-los, porque os missionários estavam envolvidos em sua organização e qual sua relação com a teologia índia. Diante dessas questões, um dos missionários, Hewesi ihurupe $\ddot{17}^{17}$, deu-nos um vídeo que, segundo ele, narrava todo o processo de organização dos encontros de xapuri. Este vídeo tem por título Xapiripë ithomihe. Juntos para a descida dos xapiripë. Encontros interregionais de fortalecimento dos pajés Yanomami, o que, por si só, exprime muito do significado que esses encontros têm para os missionários e também para alguns Yanomami. Vejamos com mais vagar este ponto.

\footnotetext{
13 Pajelança.

${ }^{14}$ Nome que lhe foi atribuído pelos Yanomami e significa branco - não índio - preto.

${ }_{15}$ Para que se tenha uma ideia do custo do transporte, um voo de Boa Vista até a Missão Catrimani custa R \$2.200,00. Para alcançar outras regiōes, como a do baixo Catrimani, por exemplo, esse valor se eleva para $\mathrm{R} \$ 2.800,00$.

${ }^{16}$ Cronologia dos encontros inter-regionais de xapuri: 2001 - Pookohipiithere, 2002 Pookohipiithere, 2003 - Xitei, 2004 - Pookohipiithere, 2005 - Mauxiuthere, 2009 - Waromapiithere, 2010 - Hawarixapopëuthere, 2011: Pookohipiithere (a ser realizada entre os dias 21 e 25/02).

${ }^{17}$ Nome Yanomami atribuído a um missionário, que significa morcego.
} 
De acordo com o vídeo, os encontros locais de pajés fazem parte do calendário ritual Yanomami e, como tal, são realizados anualmente no mesmo período do ano. No entanto, após o ano 2000, quando foi intensificado o treinamento de jovens Yanomami como professores e agentes indígenas de saúde e o salário foi introduzido entre eles, o que teve como uma de suas consequências a permanência por períodos prolongados desses jovens na cidade e também o acesso a bens de consumo antes desconhecidos, os xapuri quiseram realizar encontros mais amplos, inter-regionais. Ainda segundo a narrativa que é feita no vídeo, os xapuri, temendo que seus conhecimentos fossem extintos, solicitaram o apoio da equipe missionária da missão Catrimani para a realização de encontros dos xapuri de toda a terra Yanomami. Estes permitiriam a troca de conhecimentos entre os xamãs mais experientes e também permitiriam que jovens pudessem ser iniciados.

O vídeo foi montado tendo por eixo cinco sessões: "apresentação"18, "promoção da vida em plenitude", "fortalecimento da espiritualidade Yanomami”, "o incentivo para a formação de jovens xapuri”, "uma ocasião de diálogo inter-religioso". Em cada um desses blocos, há uma narrativa em voz off ${ }^{9}$, em português, e, nos três últimos, a reprodução de relatos de alguns indígenas sobre o encontro, em Yanomami ${ }^{20}$, tendo uma legenda com sua tradução para a língua portuguesa.

$\mathrm{O}$ eixo central de toda a narrativa relaciona-se à maneira como os missionários e as missionárias da Consolata, que atuam na missão Catrimani, concebem os Yanomami como um todo e os rituais de pajelança em particular. Nesse sentido, é interessante observar que, para eles, tomando como fonte o conteúdo do vídeo e também a observação de suas relações com os índios realizada no decorrer do trabalho de campo ${ }^{21}$, está muito

\footnotetext{
${ }^{18}$ A sessão apresentação não está denominada no vídeo, mas como a narrativa gira em torno da apresentação, para um público mais amplo, do que são os encontros de xapuri, bem como quem são os Yanomami, a denominei assim para efeito de descrição neste texto.

${ }^{19}$ Narração feita por alguém que não aparece no campo visual e contextualiza o documentário.

${ }^{20}$ Estes relatos foram feitos em duas das línguas faladas na área Yanomami.

${ }^{21}$ Transcorrido em dezembro de 2010 e janeiro de 2011.
} 
claro que os rituais de pajelança constituem rituais religiosos que devem ser respeitados e incentivados. Além disso, parece haver uma tendência a considerar os Yanomami seres religiosos por excelência, cuja maneira de ser está intrinsecamente ligada à religião. Algumas frases da narrativa em off, assim como a apresentação inicial que se faz dos xamãs, ilustram este tipo de concepção. Por exemplo, logo no começo do vídeo, é mostrada a foto de um xamã e a inscrição "Xapuri thëpë (pajés e líderes religiosos)". No decorrer do vídeo, aparecem afirmações sobre como os encontros de xapuri "favorecem a troca entre lideranças religiosas, proporcionando momentos de fortalecimento religioso, moral e cultural" e "[...] a religião é a coluna vertebral e o alicerce que sustenta a forma de ser Yanomami”22.

Embora não se faça, no vídeo, referência explícita ao que concerne às relações entre os encontros de xapuri e a teologia índia, a sessão "uma ocasião de diálogo inter-religioso" deixa transparecer as concepçôes que ancoram o apoio à demanda de colaboração na organização desses encontros. A teologia índia centra-se, de acordo com Teixeira (2009), López Hernández ${ }^{23}$ (2008) e Suess (2007), no princípio de que as populações indígenas já tinham teologias desenvolvidas antes da chegada do cristianismo e essas representam um patrimônio religioso particular que não se pode deixar desaparecer. Assim, quando pensa-se em construir um modelo de igreja que leve em consideração o outro, seria preciso pensar a missão como diálogo inter-religioso. Não se justifica, afirma López Hernández (2008, p. 5-6),

[...] que La Iglesia siga satanizando a los pueblos de culturas distintas de la occidental, mirando idolatrías y paganismos en nuestras expresiones autóctonas. Pero tampoco es necesario que ella nos idealice a partir de nuestros reales o supuestos valores, porque no somos más que expresión humana e histórica actual de lo que Dios ha obrado en nuestra historia, de la herencia recibida de nuestros antepasados y de lo que nosotros mismos hemos logrado hacer con las posibilidades que hemos tenido en esta sociedad, marcada por el pecado pero fruto también de la gracia.

\footnotetext{
${ }^{22}$ Nesse sentido, a concepção que eles têm de religião aproxima-se sobremaneira da concepção durkheiniana, segundo a qual a sociedade nasce da e na religião.

${ }^{23}$ Padre mexicano de origem indígena.
} 
Ao mesmo tempo em que López Hernández (2008) reivindica um status distinto para as expressões indígenas, ele chama a atenção para o risco de idealização dos valores indígenas. Ou seja, ele parece reivindicar para essas expressões um lugar idêntico ao que é reservado às teologias cristãs, com as quais se supõe poder travar um diálogo inter-religioso. Assim, os missionários da Consolata que atuam na missão Catrimani, ao partilharem do princípio de que os Yanomami têm suas expressóes religiosas próprias e que estas estão, sobretudo, ligadas aos rituais xamânicos, veem justificada sua ajuda na organização dos encontros de xapuri e sua participação neles, o que pode ser lido na chave da realização de um diálogo inter-religioso.

Cabe observar que o vídeo Xapiripë ithomaihe. Juntos para a descida dos xapiripë. Encontros inter-regionais de fortalecimento dos pajés Yanomami foi elaborado tendo como um de seus objetivos mostrar aos italianos que colaboraram financeiramente para que o encontro inter-regional de xapuri fosse realizado - Regione Piemonte, Impegnarsiserve Onlus, Missionários da Consolata - o que são esses encontros e o que eles representam para os missionários que atuam na missão. Esta não é, segundo Hewesi ihurupë, uma tarefa muito fácil, pois os católicos italianos têm bastante dificuldade de entender este tipo de atuação como atuação missionária e cobram dos missionários uma atuação proselitista. Por outro lado, quando trata-se de não religiosos ou de pessoas que são contrárias à atuação de missionários junto a populações indígenas, há uma reação composta por um misto de surpresa e alívio frente ao relato sobre a atuação desses missionários, justamente pelo fato deles não fazerem proselitismo. Há, em ambos os casos, de acordo com Hewesi ihurupë, uma dificuldade em entender o que esses religiosos fazem como trabalho missionário.

Este tipo de atuação missionária, que parte do princípio de que é preciso respeitar o que eles consideram como sendo as práticas religiosas dos indígenas, não é consensual nem mesmo no interior da própria Igreja Católica. Nesse sentido, vale ressaltar a polêmica levantada pelo então Cardeal Ratzinger acerca das atividades missionárias que, a seu ver, estão permeadas pelo que denomina "dogma do relativismo", que restringiria o significado e a pertinência da missão evangelizadora à medida que se pretende "[...] 
preservar ilhas pré-tecnológicas no oceano da humanidade", encerrando homens e culturas numa "reserva natural espiritual" (Ratzinger, 1995, p. 704, apud Teixeira, 2009). O "dogma do relativismo" estaria presente, segundo Ratzinger, na teologia índia latino-americana, já que esta buscaria reavivar valores de antigas religiôes do continente.

Passados doze anos, o mesmo Ratzinger, agora Papa Bento XVI, retoma estes mesmos argumentos, na Conferência de Aparecida (V Celam). De acordo com Suess (2007),

Em muitas votações, a maioria dos votos foi dos pastoralistas, mas essa maioria nem sempre se refletiu no Documento de Aparecida (DA). Pois, se nas Conferências de Puebla e Santo Domingo atuava um D. Luciano Mendes, com sua santa prudência, agora, os redatores finais são, na maioria, pessoas trazidas de Roma, cuidadosamente escolhidas e informadas sobre determinados temas proibidos (neoliberalismo, reforma ministerial, Teologia Índia...) e com teologias que não passaram pela peneira das mediações históricas e antropológicas do lugar (Suess, 2007, p. 4).

Tomando como parâmetro a afirmação de Paulo Suess (2007) acima citada, pode-se afirmar que o debate em torno do tratamento a ser dado à questão das relaçôes interculturais no interior da Igreja Católica está longe de ter uma posição consensual. Mesmo dentre aqueles que advogam em favor de posiçôes teológicas que deem espaço para a expressão de outras formas de religiosidade, não há, como se pode ver, pelo que foi exposto anteriormente, uma posição única. Há, por exemplo, uma proposta de uma teologia do sincretismo, no que concerne particularmente às relaçôes com adeptos das religiōes afro-brasileiras, e, no que se refere aos indígenas, a discussão é perpassada pela proposta da teologia índia.

\section{SINCRETISMO COMO CATEGORIA ANALÍTICA}

Inúmeros são os autores que trabalharam - e trabalham - com a noção de sincretismo. Não sendo o objetivo de, neste texto, esgotar todos os autores que utilizaram essa noção, limitar-nos-emos a citar apenas uma pequena 
parcela da produção bibliográfica sobre o tema. Iniciaremos a discussão com um autor citado na maioria dos textos que tratam da noção de sincretismo, Roger Bastide (1971).

Bastide (1971) vale-se da noção de sincretismo para pensar fenômenos de interpenetração de civilizaçôes. Segundo o autor, para explicar como e porque operam os fenômenos de interpenetração de civilizações, faz-se necessário que o pesquisador se debruce sobre o continuum histórico, o que exigiria também a análise de dados provindos de fontes documentais. Em realidade, Bastide (1971) propóe, para o estudo deste tipo de fenômeno, um método que junte a observação participante com análises sociológica, histórica e psicológica ${ }^{24}$.

Este tipo de proposta metodológica baseia-se numa argumentação que tentaremos sintetizar a seguir. Em primeiro lugar, ressalta o autor (1971), o objeto de análise são as civilizações de outrora, às quais não teríamos acesso sem o recurso a documentos, e não as atuais. Em segundo lugar, o recurso à psicologia justificar-se-ia pelo fato de que o que se coloca em contato não são as civilizaçôes, mas os homens. Desse modo, seria preciso pensar sobre seus desejos de prestígio, de melhora, de ser imitado, que não poderiam ser manifestos fora da experiência individual. Entretanto, este tipo de análise não poderia ser separada da análise sociológica, tendo em vista que os indivíduos não podem existir sem pertencer a um grupo social. Em terceiro lugar, sendo o tema de partida do autor as relaçóes entre infra e superestruturas ou, nas palavras de Bastide, o "condicionamento social da religiāo" (1971, p. 29), dever-se-ia aplicar a dialética histórica de modo a observar como, ao longo do tempo, foram criadas novas obras culturais.

Tendo então como base o arcabouço teórico-metodológico acima exposto, Bastide (1971) coloca-se, para a elaboração de seu estudo As religiōes africanas no Brasil, a pergunta sobre a reação das religiões africanas às transformações pelas quais passou a sociedade brasileira ao longo do período que durou a escravidão. A conclusão do autor é de que as mudanças que afetam os sistemas religiosos constituem-se em fenômenos de adaptação e

${ }^{24}$ Nesse sentido, o autor critica os estudiosos americanos por terem operado uma segmentação no interior das ciências humanas. 
reequilíbrio face a transformações de outra natureza. $\mathrm{O}$ argumento desenvolvido é o de que as religiôes funcionariam como suportes da memória coletiva ${ }^{25}$ e, nesse sentido, teriam uma tendência a preservar seus ritos como formas de manter vivos os seus mitos de criação. No entanto, ao depararemse com situaçôes socialmente desagregadoras, os sistemas religiosos acabam por sofrer transformações. Em suma, o autor defende que as transformações dos sistemas religiosos, situados na superestrutura, estão relacionadas às transformações da infraestrutura.

Tentando conciliar as reflexões iniciadas por Bastide com a teoria weberiana acerca da secularização, Renato Ortiz (1990, p. 213) realiza seu estudo sobre a umbanda, $A$ morte branca do feiticeiro negro. Neste, o autor propõe-se a demonstrar como se dá a integração e legitimação da umbanda na sociedade brasileira, tendo como eixo condutor a questão da mudança cultural. A conclusão a que ele chega é a de que o processo de secularização pelo qual passa a sociedade brasileira não implica o desaparecimento das crenças religiosas, mas essas podem ser "[...] reinterpretadas segundo o código fornecido pela sociedade global”. Nesse sentido, Ortiz (1990) contrapõe-se a Bastide (1971) à medida que atribui à umbanda um estatuto de religião original. Por outro lado, concorda com Bastide (1971) no que concerne aos mecanismos sincréticos que estariam na base da formação da umbanda, argumentando que a reinterpretação da tradição africana a partir de valores brancos permitiria ao negro ou mulato fugir do enclausuramento ${ }^{26}$. Em suma, na perspectiva adotada por Ortiz (1990), a noção de sincretismo é utilizada para pensar o processo de adaptação/integração dos adeptos da umbanda à sociedade global ${ }^{27}$.

Tentando sair do debate em torno da noção de sincretismo para explicar a adaptação/integração ou a resistência da população de origem africana à sociedade global, Pierre Sanchis (2001) defende o uso desta categoria

\footnotetext{
${ }^{25}$ No sentido definido por Halbwacks.

${ }^{26}$ Uma discussão acerca das críticas tecidas a este tipo de argumentação será desenvolvida mais adiante.

${ }^{27}$ Esta perspectiva foi bastante criticada por autores como Fernando Brumana, Elda González e Lísias Negrão, por exemplo.
} 
para pensar as dinâmicas de manutenção, transformação, reconfigurações, criações e recriações a partir de um eixo de representação identitária que, segundo o autor, marcam o campo religioso no Brasil. Isto porque, segundo Sanchis (2001, p. 45).

[...] uma radicalidade duradoura e constantemente reinvestida teria assim dotado o Brasil de um habitus (história feita estrutura) de porosidade das identidades e de ambivalência dos valores, de uma tendência, sempre frustrada mas permanentemente retomada, em direção à conjugação do múltiplo numa unidade nunca atingida. Com a condição de situá-la claramente em seu nível estrutural, de não confundi-la com fáceis convergências e de explicar a diversidade das versōes que, em lugares e momentos diferentes, ela apresenta, talvez continue sendo epistemologicamente produtivo chamar esta porosidade de "sincretismo" (2001).

Assim como Sanchis (2001), Patrícia Birman (2001) e Regina Novaes (2001) também defendem a possibilidade de que a categoria sincretismo possa ser produtiva para pensar as dinâmicas presentes no campo religioso. Nesse sentido, Patrícia Birman (2001) cunha a categoria "trabalho sincrético" para pensar o modo como mulheres adeptas da Igreja Universal do Reino de Deus transformaram suas experiências de possessão desenvolvidas antes de sua "passagem" ${ }^{28}$ para este culto, tentando se situar diante de uma forma de conceber o mal e a pessoa menos relativizadora e mais unificada oferecida pelo pentecostalismo. Dito de outro modo, o trabalho sincrético seria, para a autora (2001), a maneira de realizar a passagem de um a outro culto, bem como de princípios explicativos para suas aflições que marcam cada um deles.

Na mesma linha dos dois autores acima citados, Regina Novaes (2001) defende o uso da categoria sincretismo para pensar processos de continuidade e descontinuidades entre passado e presente e entre diferentes manifestações

${ }^{28}$ A autora (2001) prefere usar o termo "passagem" em lugar de conversão, dado que este último não permitiria compreender o processo extremamente complexo de rupturas e continuidades que marca a ida de uma religião a outra. 
dos fenômenos que se quer estudar. Desse modo, para a autora (2001, p. 204), sincretismo poderia ser definido como "[...] encontros que modificam crenças" e seria produtivo para compreender como "[...] as trocas culturais e a matéria-prima simbólica socialmente disponível estão construindo outra maneira de classificar e atualizar crenças e religiōes”.

Após termos apresentado, em linhas gerais, algumas definições da categoria sincretismo dadas por autores das ciências sociais, particularmente das áreas de antropologia e sociologia, passaremos a uma discussão sobre seus usos como categoria nativa e analítica.

\section{DE CATEGORIA ANALÍTICA A CATEGORIA NATIVA OU VICE-VERSA}

O impulso primeiro para escrever este texto teve por motivação a análise da adoção de uma categoria analítica como categoria nativa. Pensava, naquele momento, que a categoria sincretismo teria migrado das ciências sociais para as ciências da religião e teologia. No entanto, no decorrer da pesquisa bibliográfica sobre o sincretismo, deparei-me com informações que davam conta de que esta categoria, antes de ser adotada por cientistas sociais, já o tinha sido pela teologia e pelas ciências da religião, além de ter uma raiz etimológica que remonta à Grécia antiga. Assim sendo, minha hipótese inicial caiu por terra.

No entanto, o fato de minha hipótese original ter caído por terra, acabou dando uma nova dimensão à proposta deste texto, pois à medida que o desenvolvia, algumas questões foram surgindo. Uma das questôes que, apesar de estar presente desde o início dessa empreitada, ganhou mais corpo foi a do uso, por vezes confuso, da categoria sincretismo ora como fenômeno social, ora como categoria analítica. Esse uso não muito claro dessa categoria não é feito apenas por teólogos, mas permeia boa parte dos trabalhos de cientistas sociais que se debruçam sobre o tema. Um exemplo desse tipo de uso é o que faz Sanchis (2001) que às vezes toma sincretismo como categoria analítica, defendendo sua propriedade na análise de deter- 
minados fenômenos sociais e, outras vezes, o toma como um fenômeno social em si mesmo.

Já o uso do sincretismo apenas como dado é feito, por exemplo, por adeptos de religiôes afro-brasileiras no contexto do movimento antissincretismo, mas não se restringe a este grupo. Ao buscar o verbete syncrétisme no Dictionnaire de l'etnologie et de l'anthropologie (2002), deparamo-nos com uma definição pautada única e exclusivamente na descrição de fenômenos sociais tais quais o vodu, o kimbanguismo ou as religiōes afro-brasileiras. $\mathrm{Na}$ literatura das ciências sociais, este tipo de uso é bastante comum e seria demasiado longo e sem propósito fazer uma relação de autores que tomam sincretismo como dado. O que interessa ressaltar a partir da análise do uso desta categoria é sua fluidez ou sua capacidade de passar de um contexto a outro - de dado a conceito - sem que isso seja levado em consideração. Talvez a fluidez não seja uma característica da categoria em si mesma, mas uma decorrência de sua naturalização, particularmente por parte de cientistas sociais. Não pretendo com isso recriminar a apropriação de categorias nativas por antropólogos ou sociólogos, como foi o caso da categoria "mana”, tomada por Mauss (2004) para ajudar na construção de um arcabouço analítico sobre a obrigatoriedade da troca, mas chamar a atenção para a necessidade de que esse tipo de apropriação seja explicitado.

Quanto à apropriação de categorias analíticas por agentes vinculados a movimentos sociais, religiosos, entre outros, a única coisa que me ocorre propor é que se faça um estudo do modo como se deu a apropriação, descrevendo os sentidos que lhe foram atribuídos, os que foram abandonados ou transformados.

Outra questão que apareceu com força no decorrer da elaboração deste texto, relaciona-se ao conceito de religião. Tratar a umbanda e o candomblé como religiōes ou romarias e festas de santo como expressões de uma religiosidade ligada ao catolicismo popular já é praticamente consenso entre os cientistas sociais que se debruçam sobre temas classificados na rubrica religião. No entanto, o tratamento de rituais xamânicos ou de pajelança como religião está longe de ser uma questão teoricizada. Nesse sentido, à medida que esses rituais são classificados como religiōes indígenas, no contexto 
da teologia índia, que propõe uma prática missionária baseada no diálogo inter-religioso, recoloca-se em pauta a questão da definição do conceito de religião. Isso pode dar um novo alento ao campo de estudos sobre religião à medida que desloca o problema da religião da questão da secularização/ modernidade ou do processo de desencantamento e/ou reencantamento do mundo, inspiradas pelas análises weberianas.

Nesse sentido, cabe observar que, ao classificar as práticas xamânicas como religiōes e propor a realização de diálogos inter-religiosos, coloca-se também o problema das relações interculturais, algo caro às ciências sociais. O que está em pauta nesse caso é o modo como será tratada a alteridade no seio da Igreja Católica e, para tanto, teólogos e missionários estão se ancorando em discussões antropológicas, históricas, sociológicas, econômicas, entre outras, sobre o tema, assim como em reivindicações de movimentos identitários e afins.

É por ter-se alimentado de informações advindas de vários desses campos que aqueles que propõem a elaboração de uma teologia sincrética discutem com agentes que participaram do movimento antissincrético, aceitando, por um lado, sua recusa da classificação das religiōes afro-brasileiras como sincréticas, visto que, nesse contexto, sincrético é sinônimo de subalterno e impuro. Por outro lado, ao defenderem o uso do termo sincretismo para nomear uma teologia que pretende ter como norte a realização de diálogos inter-religiosos com adeptos de religiōes afro-brasileiras, esses teólogos ressaltam apenas alguns dos sentidos que o termo expressa, como a permanência de crenças e doutrinas oriundas de tradiçóes religiosas as mais diversas.

\section{REFERENCIAS}

BASTIDE, Roger. As religioes africanas no Brasil: contribuição a uma sociologia das interpenetrações de civilizações. São Paulo: Edusp/Pioneira, 1971. v. 1 e 2.

BIRMAN, Patrícia. Conexões políticas e bricolagens religiosas: questões sobre o pentecostalismo a partir de alguns contrapontos. In: SANCHIS, 
Pierre (Org.). Fiéis e cidadãos. Percursos de sincretismo no Brasil. Rio de Janeiro: Ed. UERJ, p. 59-86, 2001.

BRUMANA, Fernando; MARTINEZ, Elda. Feitiçaria, antifeitiçaria e resolução da aflição. Marginália sagrada. Campinas: Editora da Unicamp, 1991.

DICTIONNAIRE de l'ethnologie et de l'anthropologie. Paris: PUF, 2002.

FERRETTI, Sérgio F. Sincretismo e religião na festa do Divino. Anthropologicas, ano 11, v. 18, n. 2, p. 105-122, 2007.

HERNÁNDEZ, Eleazar López. El dilema del indio como 'otro' en la evangelización, 2008.

HOUAISS, Antônio; VILLAR, Mauro de Salles. Dicionário Houaiss da Lingua Portuguesa. Rio de Janeiro: Objetiva, 2001.

MAUSS, Marcel. O ensaio sobre a dádiva. Sociologia e antropologia. São Paulo: Cosac \& Naify, p. 183-314, 2004.

MIRANDA, Mario de França. Inculturação da fé. Uma abordagem teológica. São Paulo: Edições Loyola, 2001.

NEGRÃO, Lísias. Entre a cruz e a encruzilhada. São Paulo: Edusp, 1996.

NOVAES, Regina. Juventude e religião: marcos geracionais e novas modalidades sincréticas. In: SANCHIS, Pierre (Org.). Fiéis e cidadãos. Percursos de sincretismo no Brasil. Rio de Janeiro: Ed. UERJ, p. 181-207, 2001.

OLIVEIRA, Irene Dias. Etnicidade, religiōes e culturas em movimento: para onde vamos? In: Anais do V Simpósio Internacional do Centro de Estudos do Caribe no Brasil. Salvador, 2008.

ORTIZ, Renato. A morte branca do feiticeiro negro. Umbanda e sociedade brasileira. São Paulo: Brasiliense, 1991.

SANCHIS, Pierre. Religiões, religião... Alguns problemas do sincretismo no campo religioso brasileiro. In: Fiéis e cidadãos. Percursos de sincretismo no Brasil. Rio de Janeiro: Ed. UERJ, p. 9-57, 2001. 
SOARES, Afonso M. Ligorio. Sincretismo afro-católico no Brasil: lições de um povo em exílio. Rever, n. 3, 2002. Disponível em: www.pucsp.br/ rever/rv3_2002/t_soares.htm\#nast1\#nast1. Acesso em: 15 de dez. 2010.

- Sincretismo e teologia interconfessional. Ciberteologia. Revista de teologia e cultura, ano VI, n. 27, p. 32-52, 2009. Disponível em: http:// ciberteologia.paulinas.org.br/ciberteologia/wp-content/uploads/2009/12/02Sincretismo-e-teologia.pdf. Acesso em: 16 de dez. 2010.

SUESS, Paulo. V Celam. Nascer já é caminhar. Conferência de Aparecida confirma a caminhada da pastoral indígena. Porantim, p. 4-5, jun./jul. 2007. TEIXEIRA, Faustino. O desafio das teologias índias. Horizonte, v. 7, n. 14, p. 12-20, jun. 2009. 